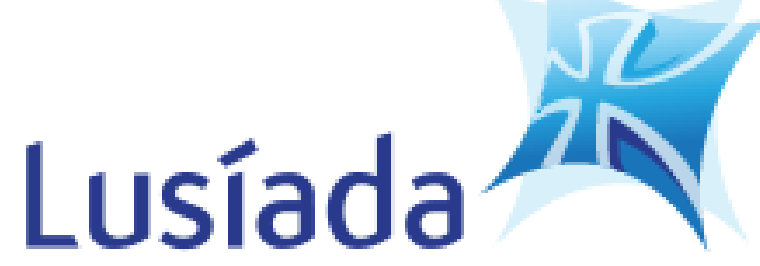

Repositório das Universidades Lusíada

\title{
Universidades Lusíada
}

Jones, David N.

\section{Global agenda for social work and social development}

http://hdl.handle.net/11067/5345

https://doi.org/10.34628/68nm-1f71

\section{Metadados}

Data de Publicação

2011

Palavras Chave

Serviço social - Filosofia

Tipo article

Revisão de Pares

Não

Coleções [ULL-ISSSL] IS, n. 38 (2011)

Esta página foi gerada automaticamente em 2023-04-26T12:51:25Z com informação proveniente do Repositório 

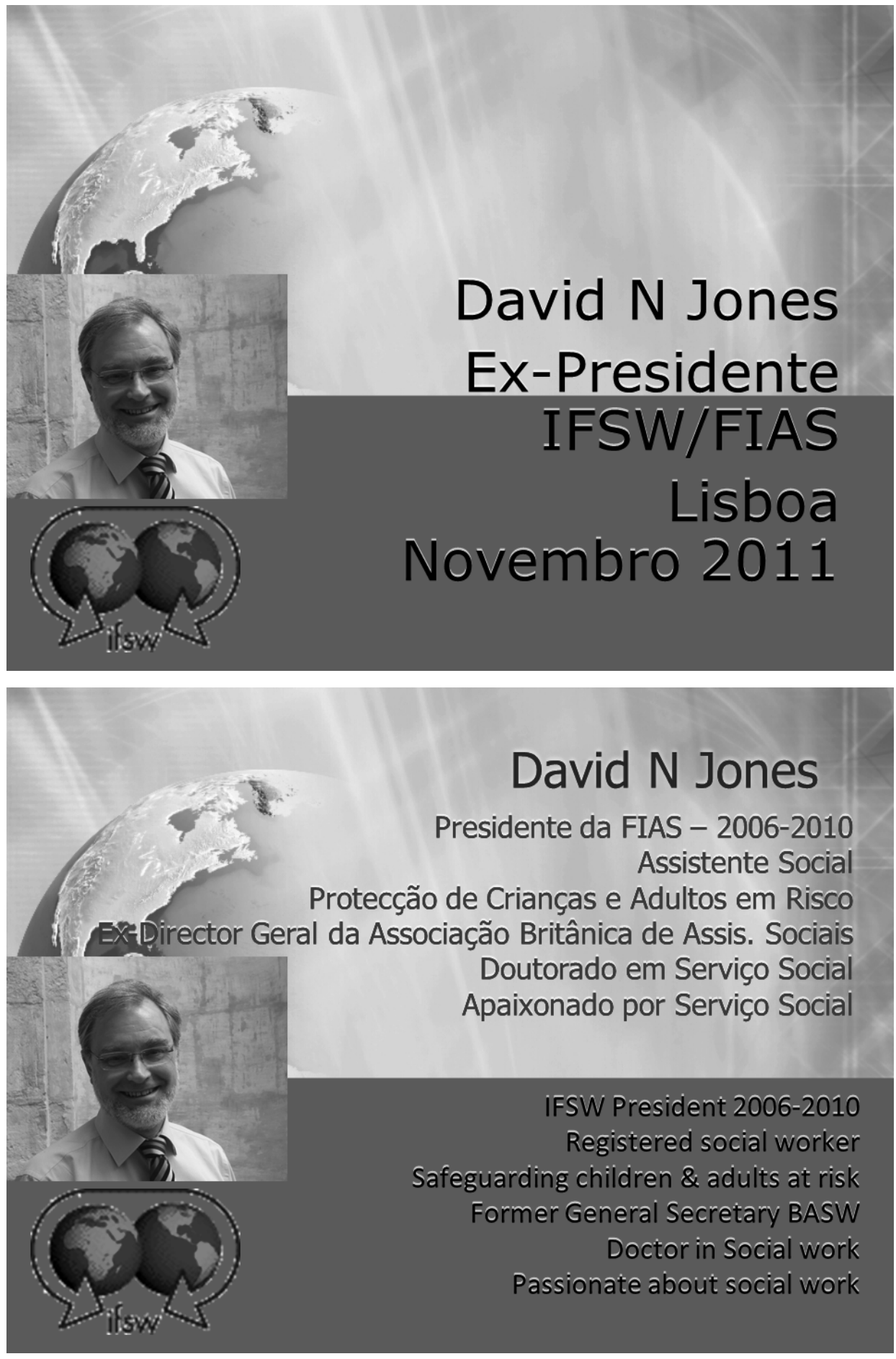

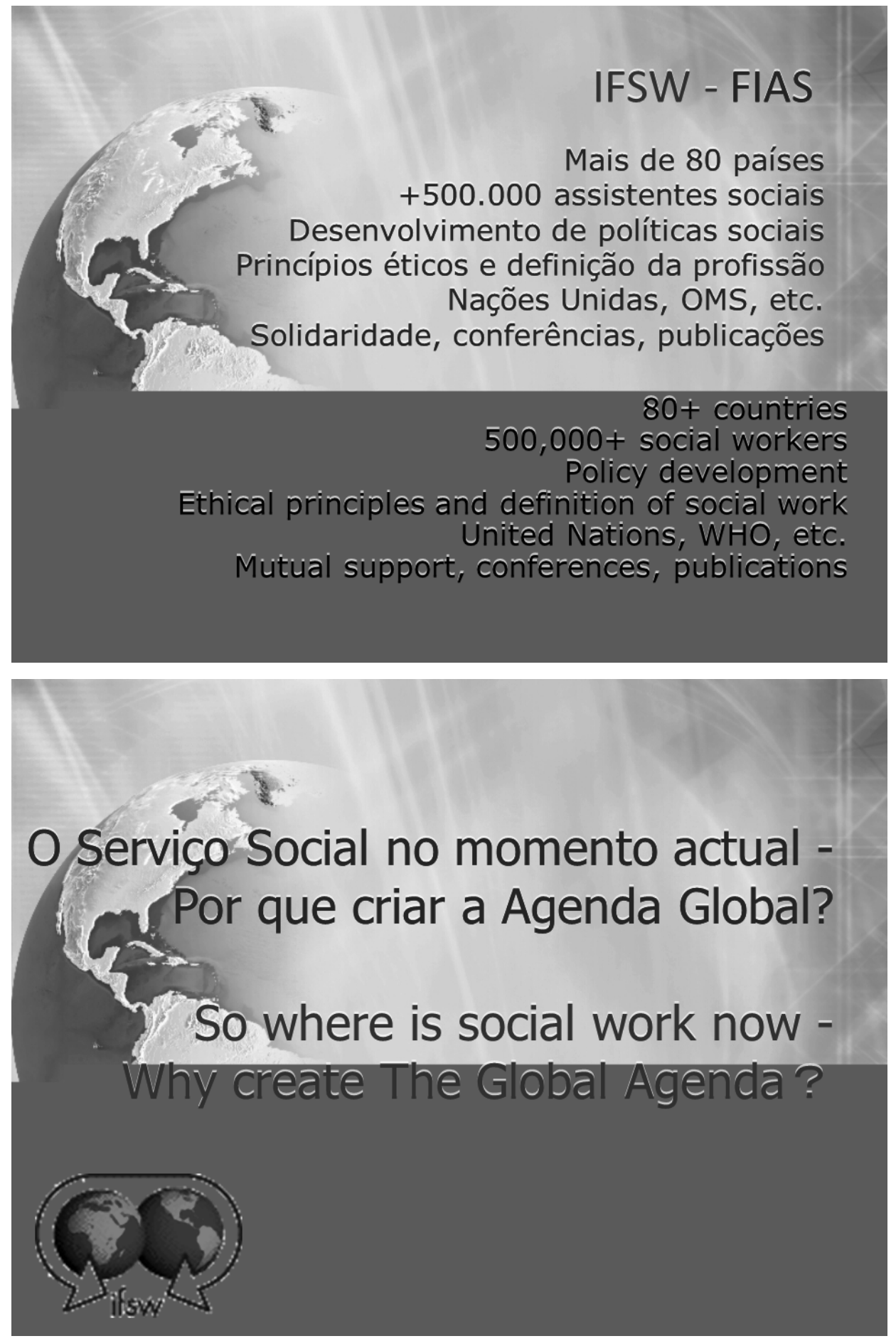

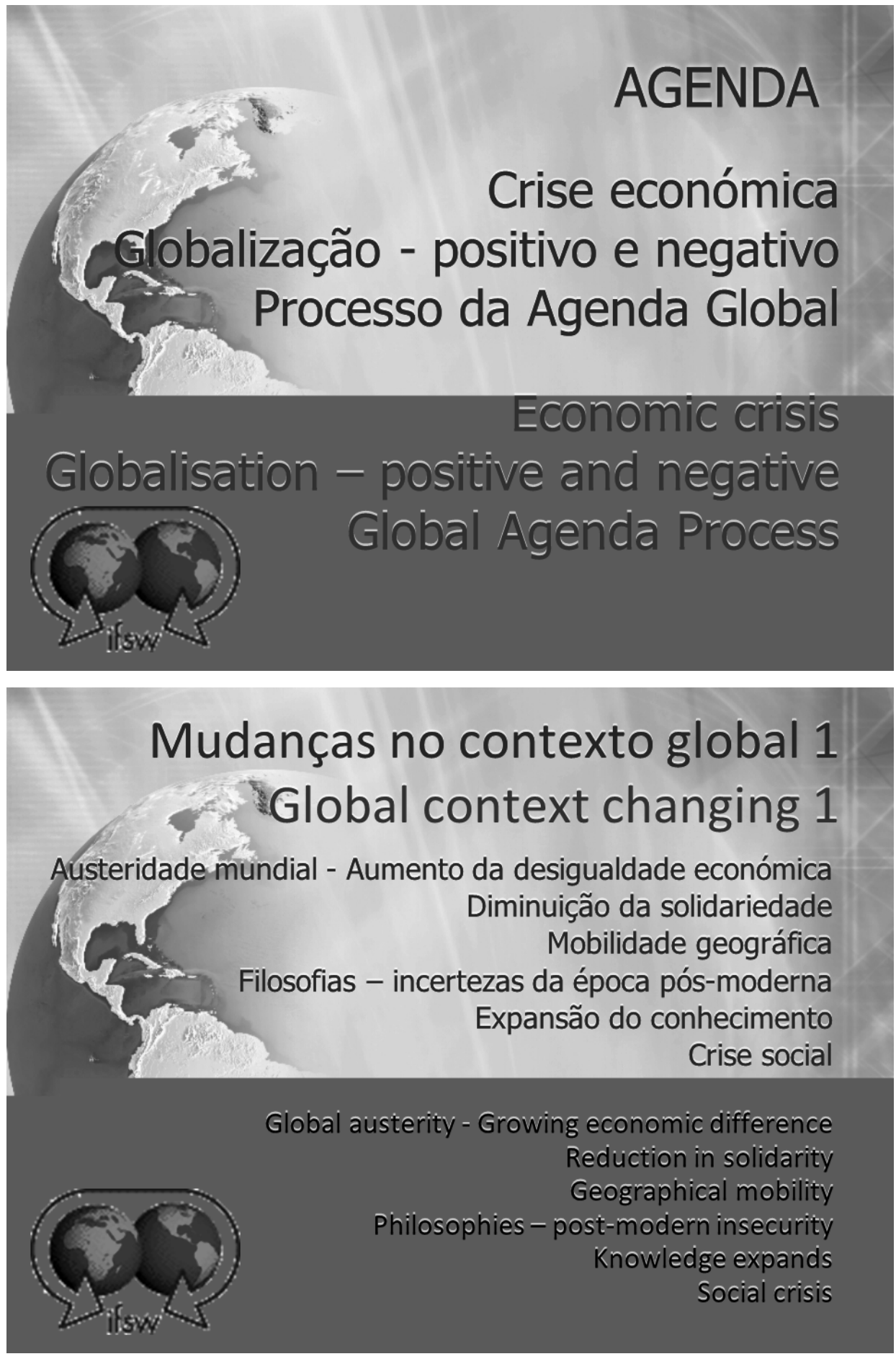


\section{Mudanças no contexto global 2 Global context changing 2}

O Serviço Social é uma profissão internacional Globalização dos assistentes sociais

Globalização dos problemas sociais - enfermidades e h epidemias, meio ambiente, indivíduos, famílias e comunidades

Social work is an international profession

- Globalisation of social workers

- Globalisation of social problems - disease and epidemics, environment, individuals, families and communities

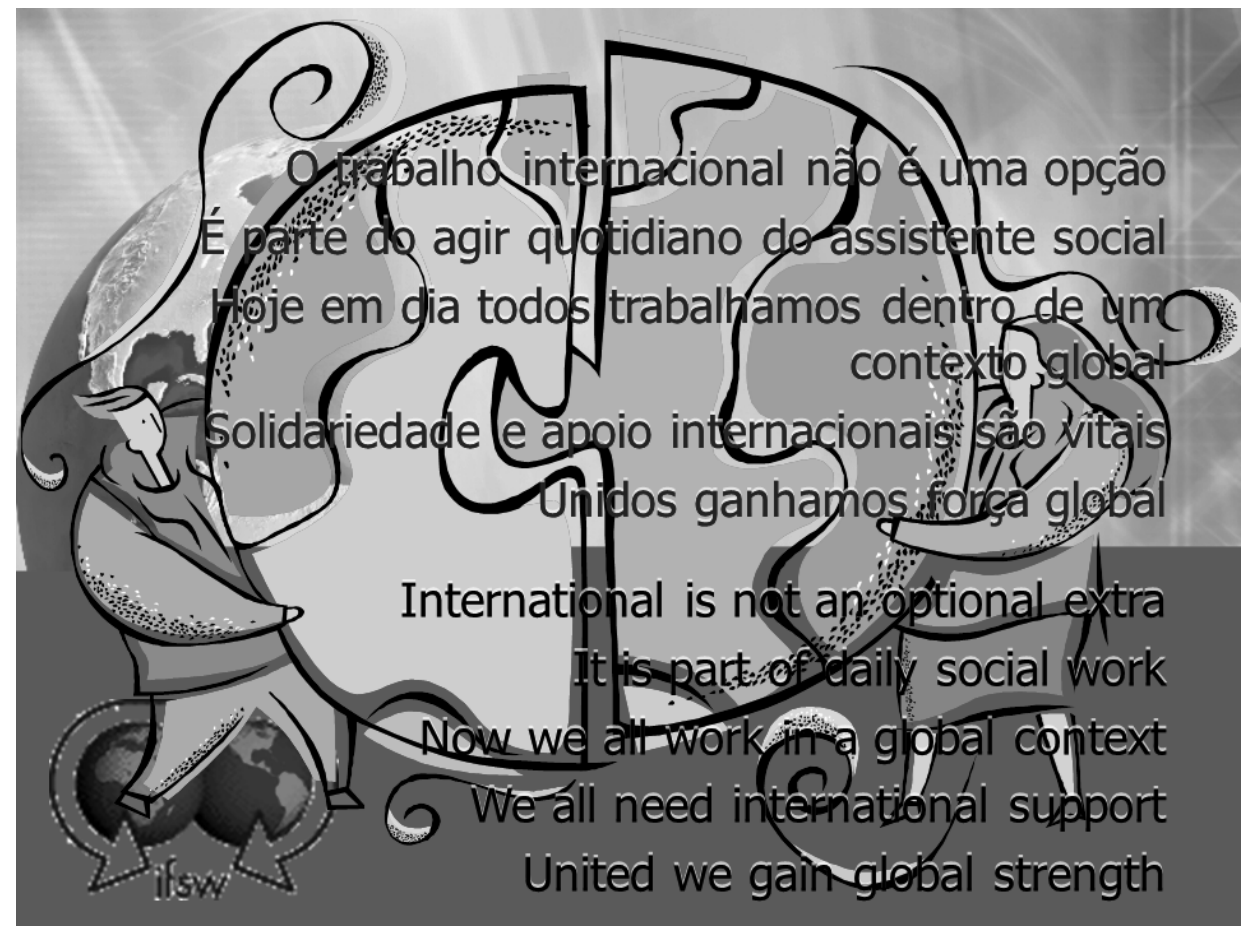




\section{Interdependência Interdependence}

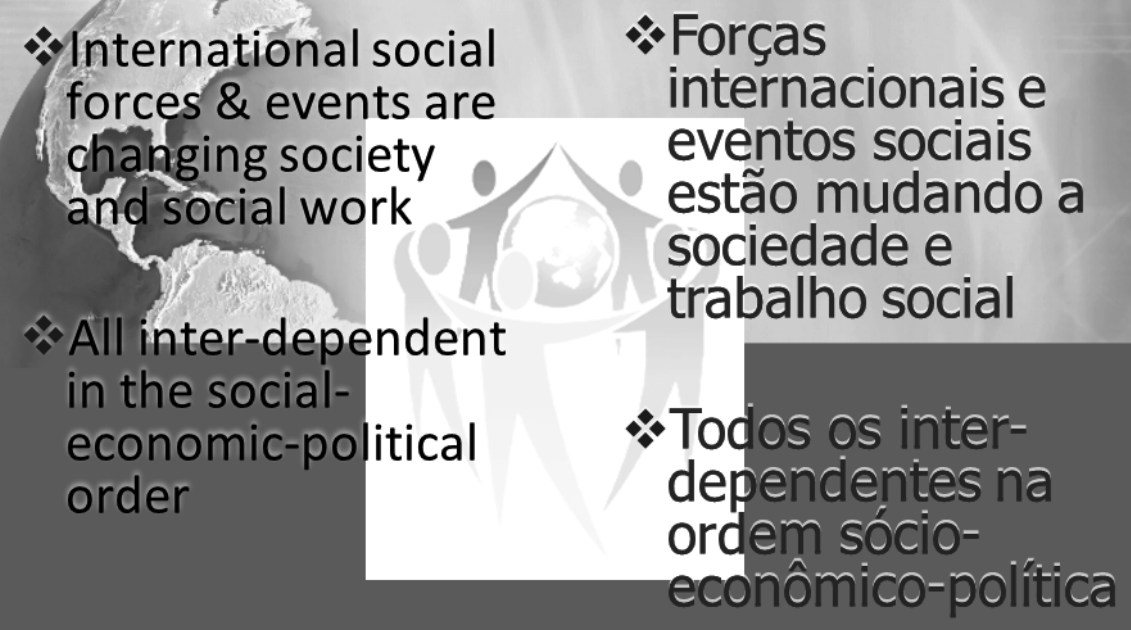

in the social-

in the socialeconomic-political order
internacio internacionais e eventos sociais estão mudando a sociedade e trabalho social

Todos os interdependentes na ordem socioeconômico-política

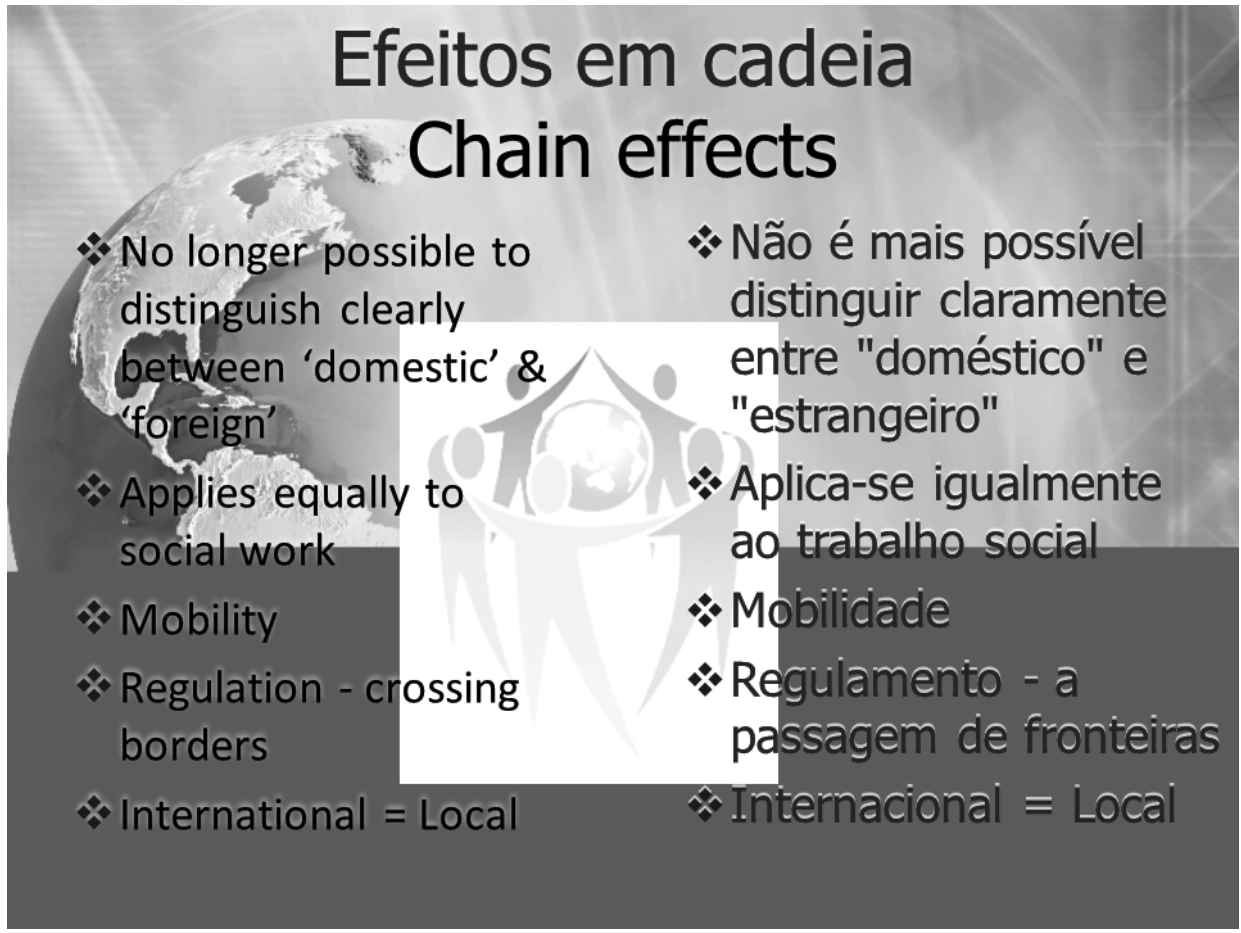




\section{Crise social? Social crisis?}

Are all these trends building to a global social crisis?
* Estarão todas essas tendências a construir uma crise social?

\section{Social Global Crisis" - Nações Unidas "Global Social Crisis" - United Nations}

\. This image cannot currently be displayed.

The image part with relationship ID rId4 was not found in the
file. 
"..políticas econômicas consideradas isoladamente de seus resultados sociais pode ter conseqüências terríveis para a pobreza, emprego, saúde, nutrição e educação ...

ShazZukang (Nações Unidas Subsecretário Geral parka os Assuntos Sociais)

s.

".. economic policies considered in isolation from their social outcomes can have dire consequences for poverty, employment, nutrition, health and education..."

Sha Zukang (United Nations Under Secretary General for Social Affairs)

\section{Crise social? Social crisis?}

Governments looking for solutions

* Keyrole for social work - providing knowledge, information and skills to influence policy \& practice
* Governos à procura de soluções * Papel fundamental para o trabalho social - fornecimento de informações, conhecimentos e capacidades para influenciar a política e prática 


\section{Sem soluções fáceis No easy solutions}

* Complex, difficult problems

* Problemas complexos

Needinformed, e difíceis knowledgeable and skilful responses

* Need flexibility and creativity

* Change \& anxiety

* Necessidade de respostas fundamentadas e adequadas

* Necessidade de flexibilidade e criatividade ^ Mudança e ansiedade

\section{Por que criar a Agenda Global? Why create The Global Agenda?}

Assistentes sociais estão à procura de liderança A Voz do trabalho social precisa de ser ouvida mais alto nas instituições globais

Tfa balthando para aprovar uma agenda comum cria força Nós temos experiências importantes para partilhar e um dever ético de falar

Social workers are looking for leadership Social work voice needs to be louder in global institutions Working to agree a common agenda creates strength We have important experiences to share and an ethical duty to speak out 

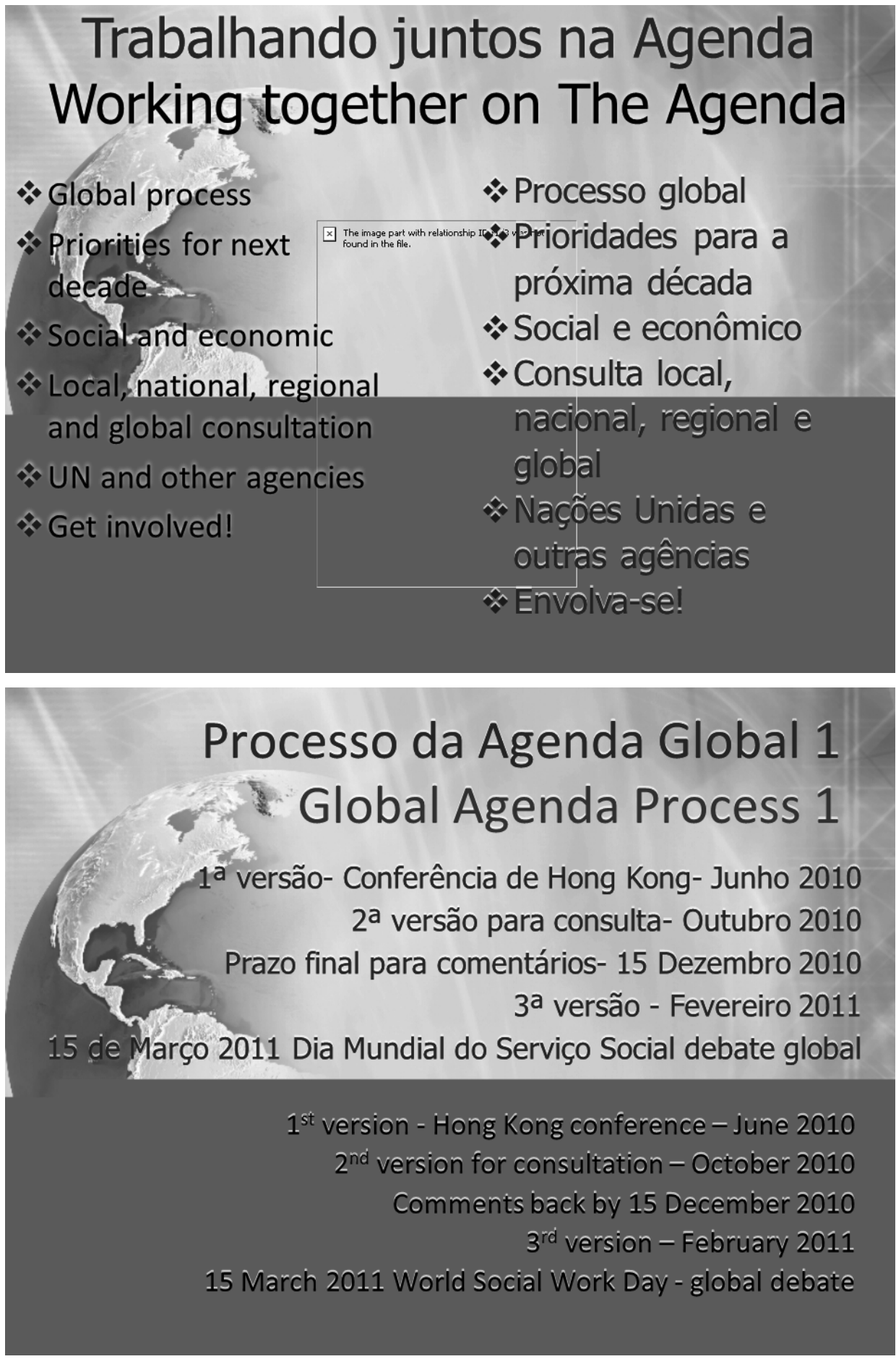

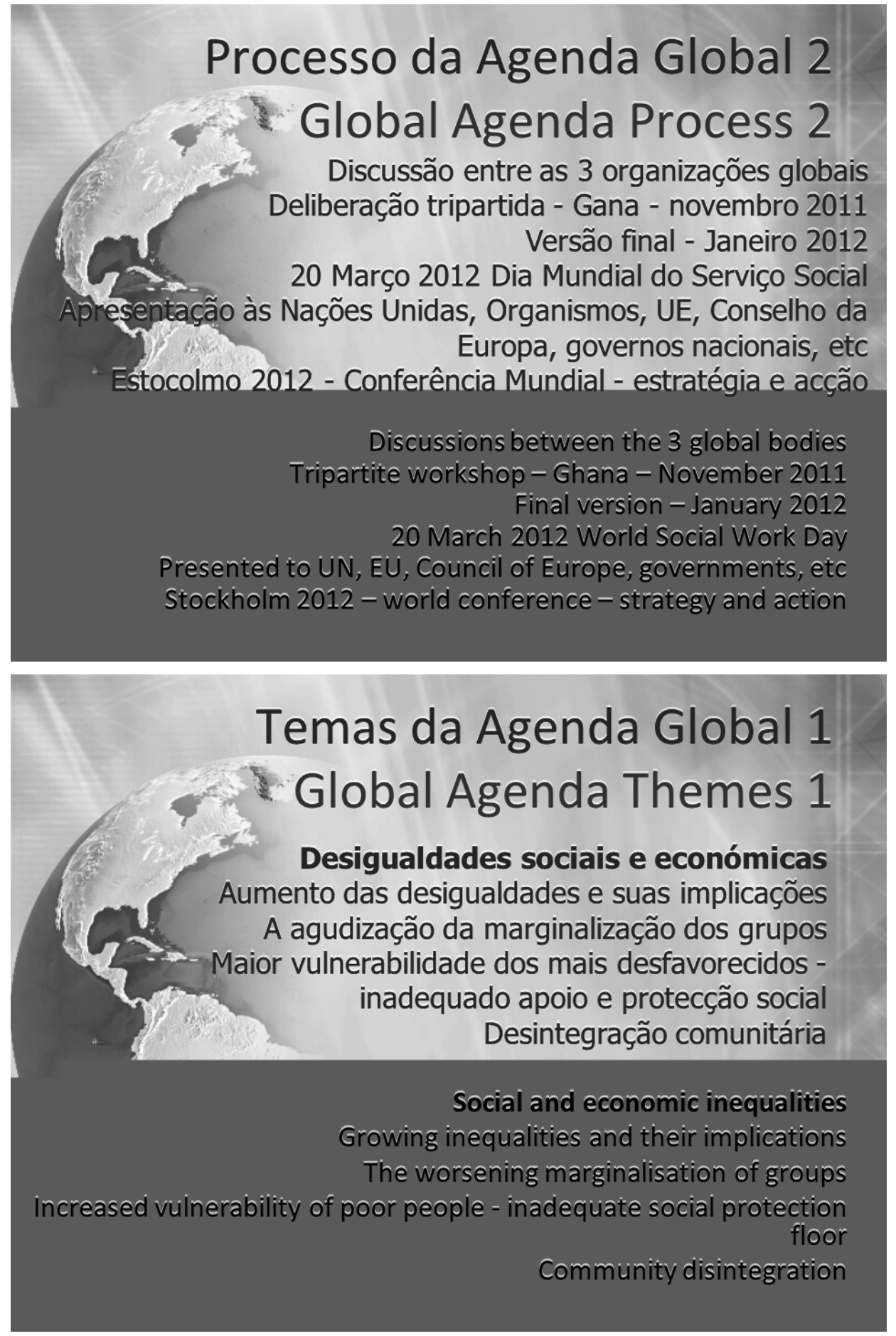

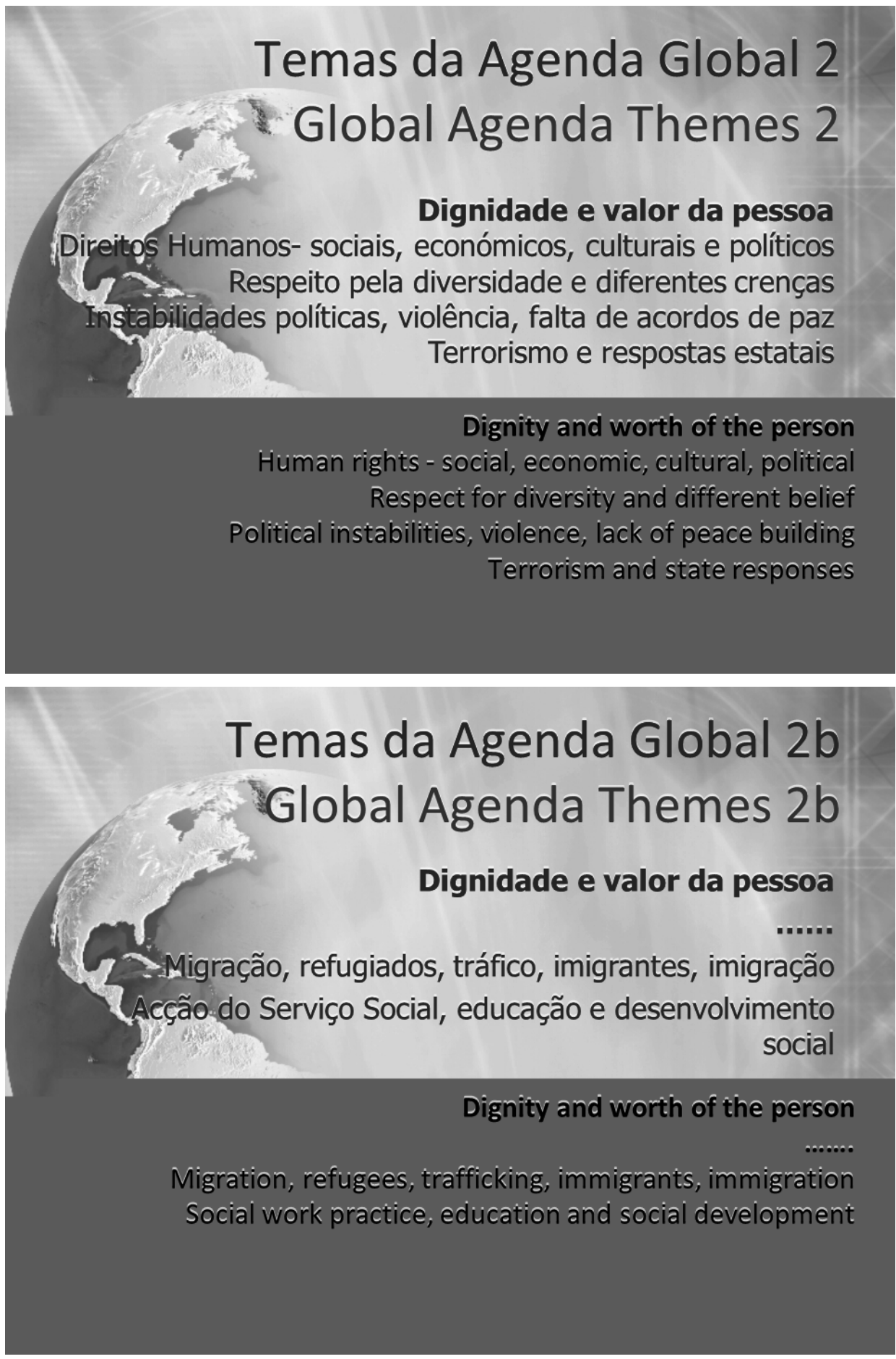

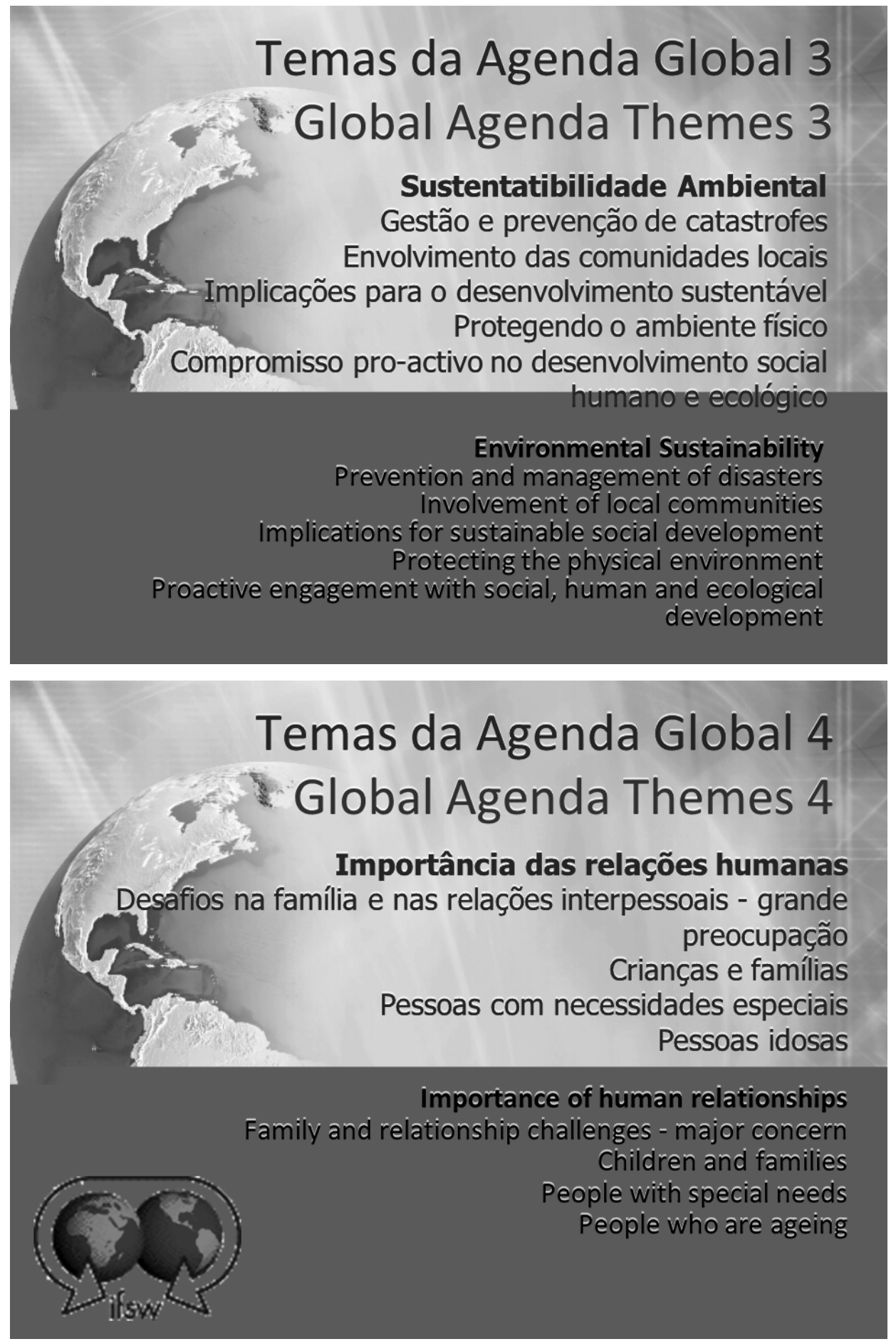

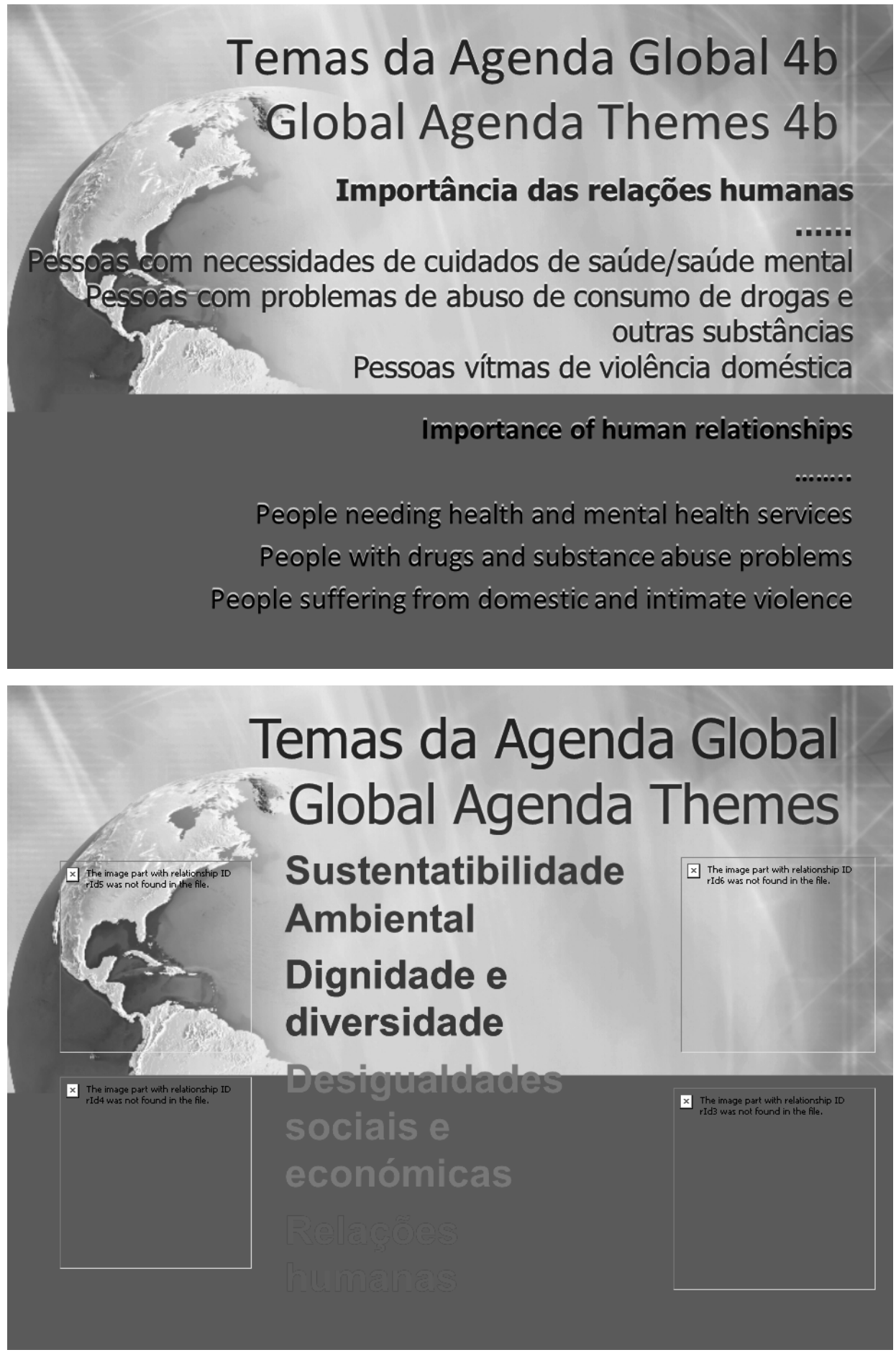


\section{Qual é a agenda? What is 'The Agenda'?}

* Global manifesto or action programme - priorities for next decade

* Guide for action and cooperation for the 3 organisations

* Manifesto global ou programa de acção - as Drón década

* Guia para a acção e cooperação entre as 3

- Basis for discussion with UN organizações agencies and others

* Call to global action -failing MDGs

* Framework for a new social summit?

* Base de discussão com as agências da ONU e outros * Chamada para a acção global - ODM falihando * Enquadramento para uma nova cimeira social?
Dia Mundial do Serviço Social 20 Marȩo 2012

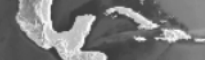
Wort Social 1 week Work Day 20 March 2012
Nações Unidas Dia do Serviço Social 1 semana 26 Março 2012 United Nations Social Work Day 26 March 2012

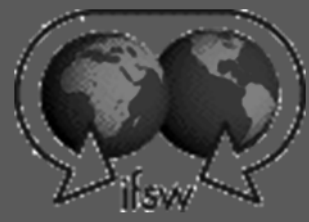



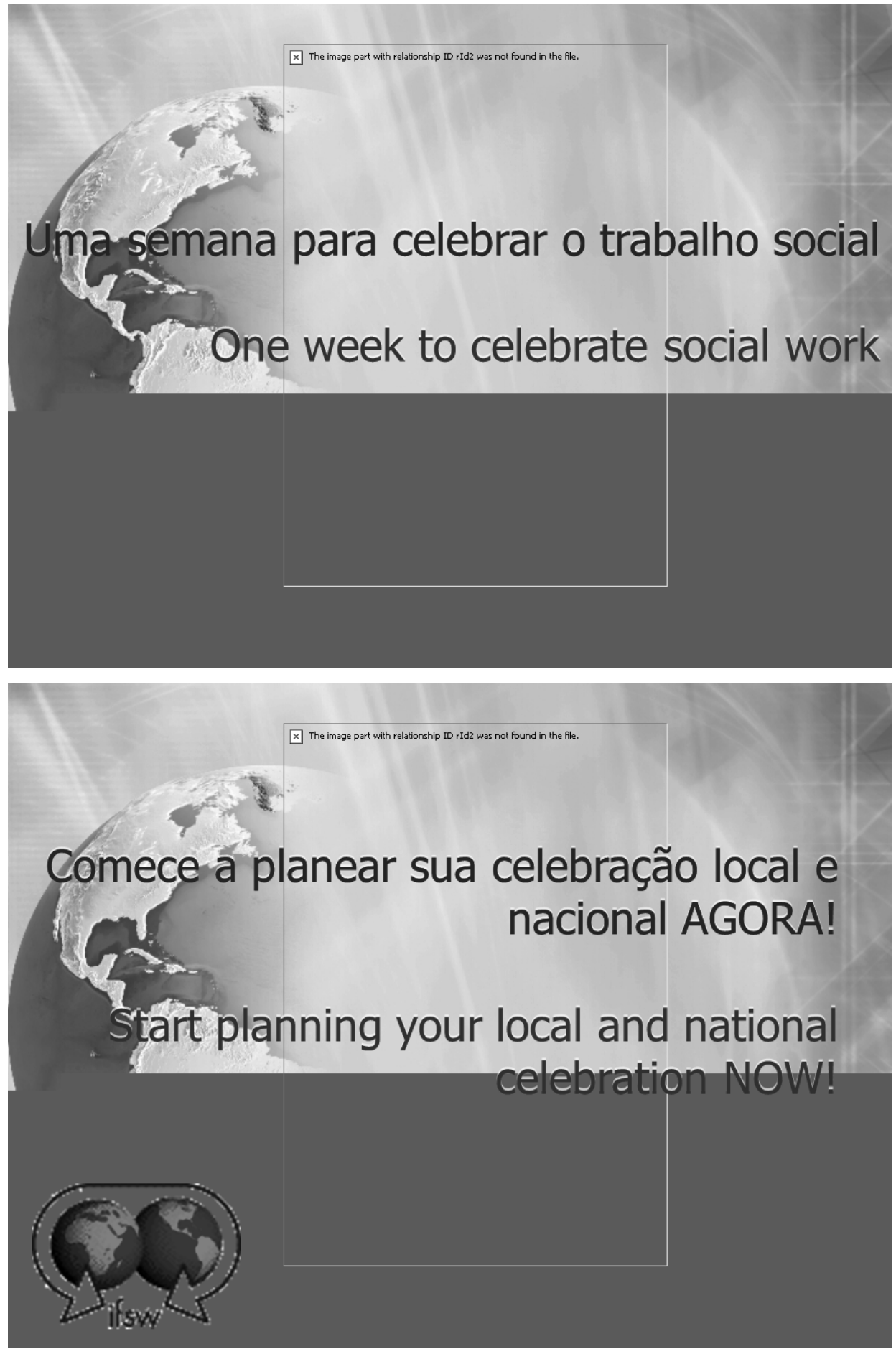

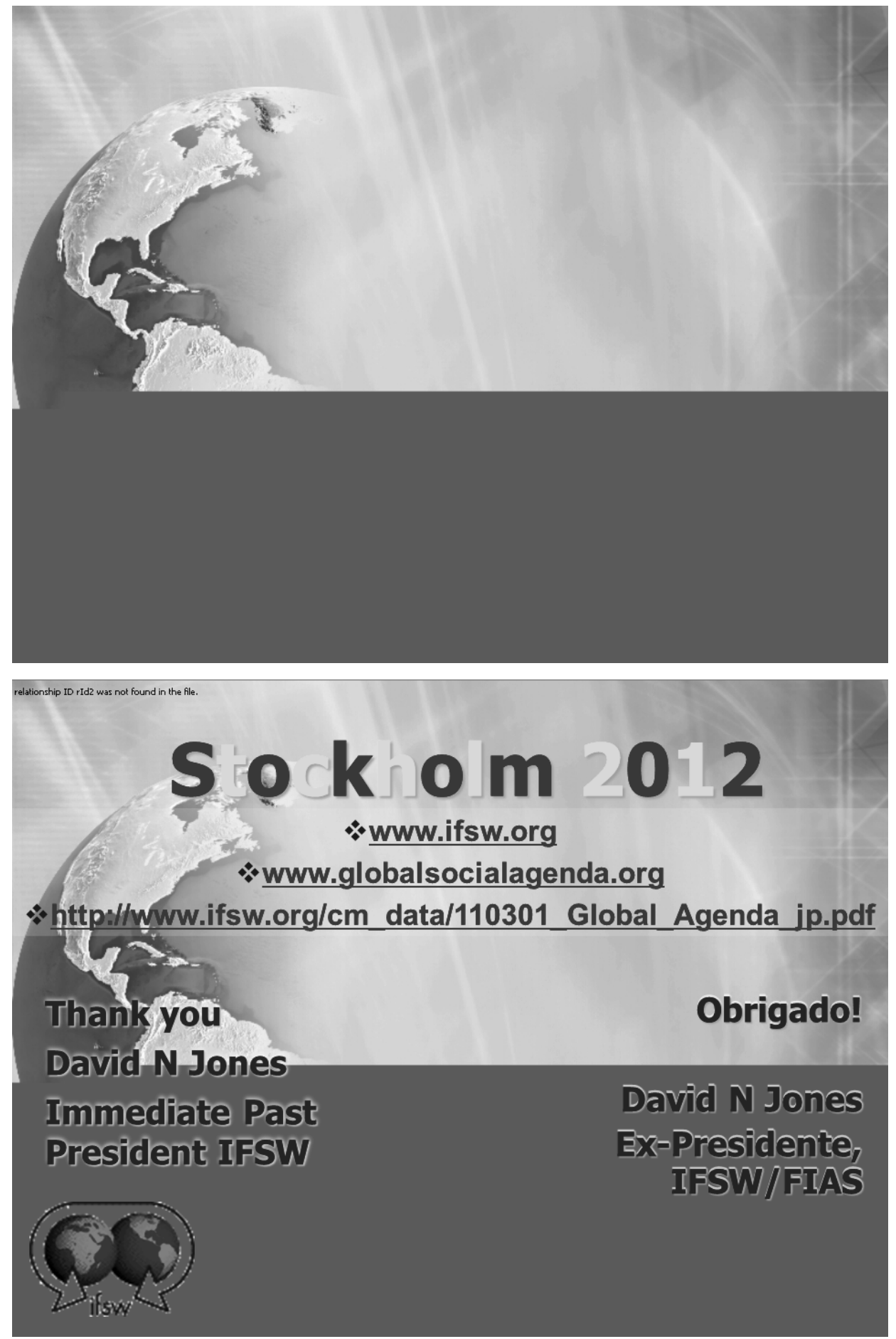